\title{
Cefazolin Irreversibly Inhibits Proliferation and Migration of Human Mesenchymal Stromal Cells
}

\author{
Hakan Pilge, Julia Fröbel, Sabine Lensing-Höhn, Christoph Zilkens, and Rüdiger Krauspe \\ Department of Orthopaedic Surgery, Heinrich-Heine-University, 40225 Düsseldorf, Germany \\ Correspondence should be addressed to Hakan Pilge; hakan.pilge@med.uni-duesseldorf.de
}

Received 11 January 2016; Revised 29 February 2016; Accepted 1 March 2016

Academic Editor: Abdelwahab Omri

Copyright (C) 2016 Hakan Pilge et al. This is an open access article distributed under the Creative Commons Attribution License, which permits unrestricted use, distribution, and reproduction in any medium, provided the original work is properly cited.

\begin{abstract}
Drugs may have a significant effect on postoperative bone healing by reducing the function of human mesenchymal stromal cells (hMSC) or mature osteoblasts. Although cefazolin is one of the most commonly used antibiotic drugs in arthroplasty to prevent infection worldwide, there is a lack of information regarding how cefazolin affects hMSC and therefore may have an effect on early bone healing. We studied the proliferation and migration capacity of primary hMSC during cefazolin treatment at various doses for up to 3 days, as well as the reversibility of the effects during the subsequent 3 days of culture without the drug. We found a timeand dose-dependent reduction of the proliferation rate and the migratory potential. Tests of whether these effects were reversible revealed that doses $\geq 250 \mu \mathrm{g} / \mathrm{mL}$ or treatments longer than $24 \mathrm{~h}$ irreversibly affected the cells. We are the first to show that application of cefazolin irreversibly inhibits the potential of hMSC for migration to the trauma site and local proliferation. Cefazolin should be administered only at the required dosage and time to prevent periprosthetic infection. If long-term administration is required and delayed bone healing is present, cefazolin application must be considered as a cause of delayed bone healing.
\end{abstract}

\section{Introduction}

In orthopaedic surgery, antibiotics are applied to significantly reduce the incidence of infection and osteomyelitis $[1,2]$. Cefazolin is a first-generation cephalosporin, which is used as a single-shot parenteral antibiotic or is locally applied in bone cement during orthopaedic surgery $[3,4]$. It is a $\beta$-lactam antibiotic, which inhibits cell wall synthesis of the bacteria. Cefazolin is $90 \%$ bactericidal to S. aureus at concentrations greater than $100 \mu \mathrm{g} / \mathrm{mL}$, which can be reached with a single $2 \mathrm{~g}$ dose $[5,6]$. Notably, reports show that bone and soft tissue concentration depend on obesity/body-mass-index (BMI), patients' age, and method of application (e.g., local application with bone cement versus systemic application). Therefore, serum and local concentrations may differ and reach lower or even high and toxic levels [7-11].

Perioperative antibiotic prophylaxis in orthopaedic surgery is usually performed with a single intravenous dose at the time of anaesthesia induction [12]. If the surgery lasts more than $3-4 \mathrm{~h}$ or the half-life of the antibiotic is short, additional doses every $4-8 \mathrm{~h}$ are recommended [13] or prophylaxis longer than $24 \mathrm{~h}$ is performed, especially when the operating environment is poor [12].

Although cefazolin is the most commonly used antibiotic drug in arthroplasty antibiotic prophylaxis worldwide [3, 14], there exist only a few reports of how it affects human osteoblasts and its progenitor cells and, therefore, how it may affect postoperative bone healing $[15,16]$. There are several reports that antibiotic drugs have a significant effect on osteoblasts. Cefuroxime, for example, showed a dosedependent increase in proliferation and alkaline phosphatase activity of human osteoblasts in vitro [9]. In addition, other antibiotics, such as clindamycin and rifampicin, have in vitro effects on osteoblasts or their progenitor cells [10, 17].

The aim of this study was to evaluate the effect of cefazolin, the most commonly used antibiotic worldwide during arthroplasty, on hMSC. To better understand the effect of cefazolin on the early stages of bone healing, the modulation of cell migration and proliferation and its reversibility was evaluated and compared to cell cultures without drug administration. 


\section{Material and Methods}

The study protocol was approved and authorised by the ethical committee of our institution. Written informed consent was obtained from all patients before surgery. During elective surgery, bone marrow was harvested from the iliac crest or the femoral head in 13 patients. Median age was 56 years (range 17 to 73 ) in 8 male and 5 female patients. None of the patients had a history of bone marrow pathologies.

2.1. MSC Isolation and Expansion. Bone marrow mononuclear cells were separated by density-gradient centrifugation (Biocoll $1.077 \mathrm{~g} / \mathrm{mL}$, Biochrom GmbH, Berlin, Germany) and seeded in growth medium (DMEM low glucose [Sigma-Aldrich, St. Louis, MO, USA], 20\% foetal bovine serum [FBS Superior, Biochrom $\mathrm{GmbH}$ ], and $1 \%$ penicillin/streptomycin/L-glutamine [Sigma-Aldrich]) in a humidified atmosphere at $37^{\circ} \mathrm{C}$ and $5 \% \mathrm{CO}_{2}$. After one week nonadherent cells were removed, and growth medium was changed every 3-4 days. Adherent cells were passaged weekly and seeded at 5000 cells $/ \mathrm{cm}^{2}$. Experiments were carried out using MSCs derived from passage 3. Before that, the MSC character of the cultured cells was determined and possible contamination with haematopoietic cells excluded by flow cytometry ( $\geq 95 \%$ expression of CD73, CD90, and CD105, while lacking CD34 and CD45).

2.2. MSC Migration. For each concentration and time point of drug treatment, $10^{5}$ trypsinized MSCs from 13 donors were resuspended in medium without drugs or FBS and were placed in cell culture inserts with $8 \mu \mathrm{m}$ pores (Greiner Bio-One $\mathrm{GmbH}$ ). The inserts were placed in 12-well plates containing growth medium with $50 \mathrm{ng} / \mathrm{mL}$ stromal cellderived factor $1 \alpha$ SDF- $1 \alpha$ (PeproTech, Rocky Hill, NJ, USA) as a chemoattractant. After $20 \mathrm{~h}$ of incubation in a humidified atmosphere at $37^{\circ} \mathrm{C}$ and $5 \% \mathrm{CO}_{2}$, cells that had migrated to the lower chamber were trypsinized and counted.

2.3. MSC Proliferation. Passage 3 MSCs were seeded at a density of 5000 cells $/ \mathrm{cm}^{2}$ and allowed to stabilize overnight before they were cultured for 24,48 , and $72 \mathrm{~h}$ with 50 , $100,250,500$, or $1000 \mu \mathrm{g} / \mathrm{mL}$ cefazolin or a negative control without antibiotics. Then cells of all 13 donors were washed with phosphate buffered saline (PBS) and trypsinized (Trypsin-EDTA solution, Sigma-Aldrich), and the cell count and viability were determined using a haemocytometer. In addition, cells treated with cefazolin for 24 or $48 \mathrm{~h}$ were cultured for another $72 \mathrm{~h}$ without antibiotics to test the reversibility of the effects.

2.4. Statistics. Statistical analyses were performed using GraphPad Prism (version 5.01, GraphPad Software Inc., San Diego, California). Values are reported as means with standard error of the mean (SEM). Statistical differences between groups treated with cefazolin and untreated controls were analysed using Student's $t$-test. A $p$ value $<0.05$ was considered significant. Asterisks are used to show the level of significance throughout the figures $\left({ }^{*} p<0.05,{ }^{* *} p<0.01\right.$, and $\left.{ }^{* * *} p<0.001\right)$.
TABLE 1: Migration after preincubation with cefazolin.

\begin{tabular}{lccc}
\hline $\begin{array}{c}\text { Cefazolin } \\
{[\mu \mathrm{g} / \mathrm{mL}]}\end{array}$ & $24 \mathrm{~h}$ cefazolin & $48 \mathrm{~h}$ cefazolin & $72 \mathrm{~h}$ cefazolin \\
\hline 0 & $56.1 \% \pm 4.2 \%$ & $43.3 \% \pm 6.0 \%$ & $27.7 \% \pm 4.6 \%$ \\
50 & $59.6 \% \pm 5.9 \%$ & $38.5 \% \pm 5.5 \%$ & $24.3 \% \pm 3.2 \%$ \\
100 & $51.2 \% \pm 8.2 \%$ & $33.9 \% \pm 5.1 \%$ & $22.4 \% \pm 3.7 \%$ \\
250 & $51.9 \% \pm 7.2 \%$ & $30.7 \% \pm 5.7 \%$ & $15.4 \% \pm 2.9 \%$ \\
500 & $39.7 \% \pm 4.4 \%$ & $15.1 \% \pm 3.3 \%$ & $7.1 \% \pm 2.0 \%$ \\
1000 & $33.7 \% \pm 5.3 \%$ & $7.1 \% \pm 1.1 \%$ & $0.4 \% \pm 0.3 \%$ \\
\hline
\end{tabular}

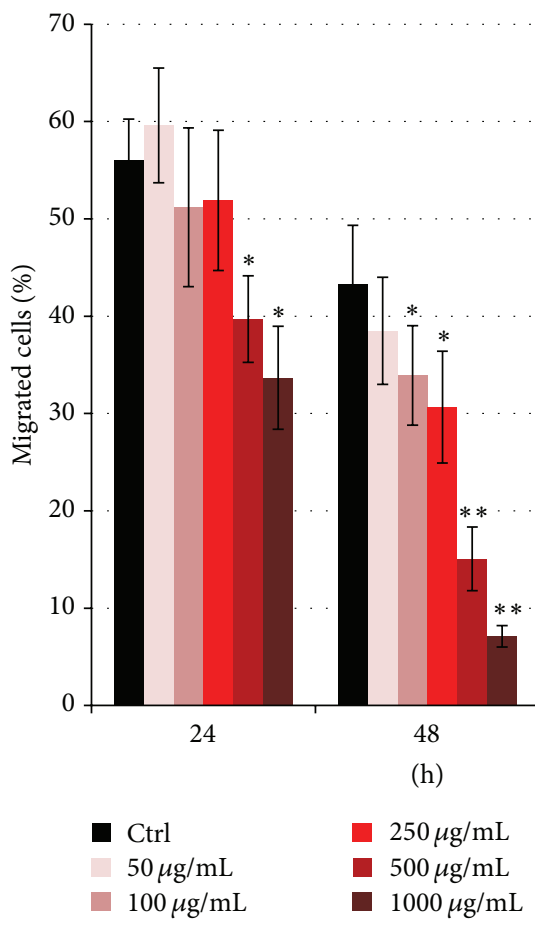

FIGURE 1: Cefazolin affects MSC migration. Bar chart showing mesenchymal stromal cells $(n=13)$ that migrated towards SDF-1. There was a significantly reduced migratory potential upon cefazolin treatment in a time- and dose-dependent manner. Asterisks show the level of significance $\left({ }^{*} p<0.05,{ }^{* *} p<0.01\right.$, and $\left.{ }^{* * *} p<0.001\right)$.

\section{Results}

3.1. Cefazolin Affects MSC Migration. The overnight Boyden chamber migration assay was carried out immediately after each time point at which the cefazolin-treated cells and untreated controls were harvested. The longer the cells were in culture, the fewer the MSCs were able to migrate. After $24 \mathrm{~h}$ of culture, $56.1 \%$ of the control MSCs migrated towards the chemoattractant, while after 48 and $72 \mathrm{~h}$, only $43.3 \%$ and $27.7 \%$ migrated, respectively $(p<0.05$ for each, Table 1 and Figure 1). Furthermore, the assay revealed that cefazolin treatment of the cells resulted in a dose- and time-dependent downregulation of the migratory potential of the MSCs. After $24 \mathrm{~h}$ of treatment, significant effects on MSC migration were seen at $500 \mu \mathrm{g} / \mathrm{mL}$ cefazolin and $1000 \mu \mathrm{g} / \mathrm{mL}$. After $48 \mathrm{~h}$, migration was significantly diminished in all cells treated 
TABLE 2: MSC proliferation under cefazolin treatment.

\begin{tabular}{lccc}
\hline $\begin{array}{l}\text { Cefazolin } \\
{[\mu \mathrm{g} / \mathrm{mL}]}\end{array}$ & 24 h cefazolin & $\begin{array}{c}\text { Cell count after } \\
48 \mathrm{~h} \text { cefazolin }\end{array}$ & 72 h cefazolin \\
\hline 0 & $173.000 \pm 17.018$ & $382.625 \pm 36.930$ & $525.000 \pm 59.806$ \\
50 & $160.000 \pm 19.330$ & $326.375 \pm 28.588$ & $428.125 \pm 49.641$ \\
100 & $153.250 \pm 21.659$ & $303.438 \pm 25.438$ & $384.688 \pm 56.617$ \\
250 & $146.500 \pm 18.587$ & $262.500 \pm 28.062$ & $293.750 \pm 31.886$ \\
500 & $118.750 \pm 17.506$ & $185.875 \pm 23.578$ & $155.000 \pm 21.044$ \\
1000 & $109.375 \pm 13.634$ & $121.250 \pm 16.764$ & $62.500 \pm 12.956$ \\
\hline
\end{tabular}

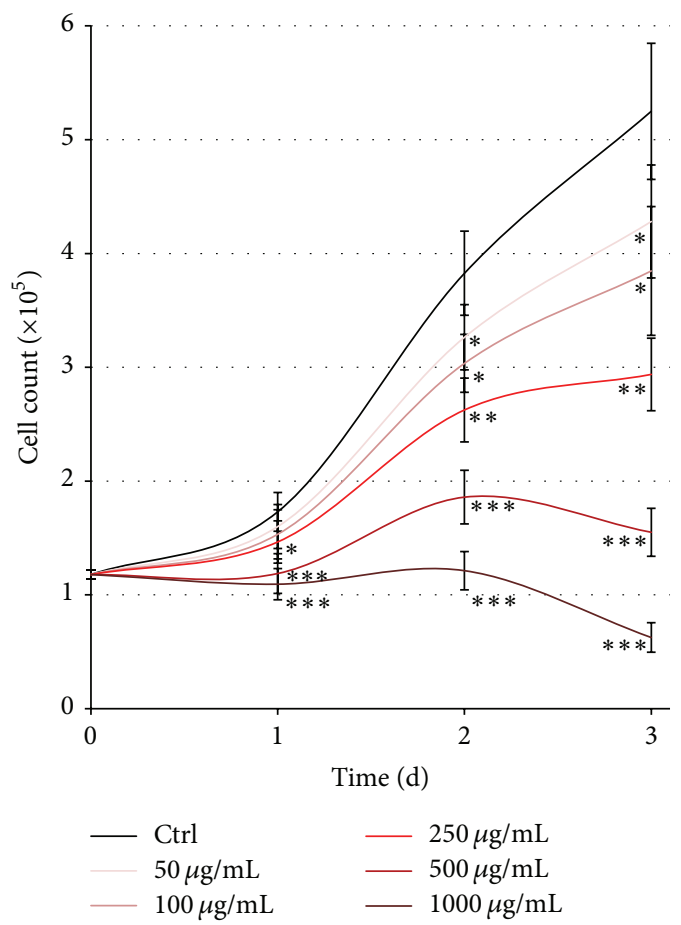

FIGURe 2: Cefazolin affects MSC proliferation. Proliferation curves showing that the cell count of mesenchymal stromal cells $(n=13)$ treated with cefazolin is significantly downregulated in a time- and dose-dependent manner. Asterisks show the level of significance $\left({ }^{*} p<0.05,{ }^{* *} p<0.01\right.$, and $\left.{ }^{* * *} p<0.001\right)$.

with $100 \mu \mathrm{g} / \mathrm{mL}$ to $1000 \mu \mathrm{g} / \mathrm{mL}$ cefazolin. The same effects could be seen after $72 \mathrm{~h}$ of cefazolin treatment.

3.2. Cefazolin Affects MSC Cell Count. Studying cell lines treated with cefazolin at five different concentrations after 24, 48 , and $72 \mathrm{~h}$, we found a significantly downregulated doseand time-dependent cell count (Table 2 and Figure 2). After $24 \mathrm{~h}$, compared to untreated controls, MSCs treated with the three highest doses of 250, 500, and $1000 \mu \mathrm{g} / \mathrm{mL}$ cefazolin showed a significantly lowered cell number. After $48 \mathrm{~h}$ and $72 \mathrm{~h}$, even MSCs treated with $50 \mu \mathrm{g} / \mathrm{mL}$ and $100 \mu \mathrm{g} / \mathrm{mL}$ cefazolin showed a significantly reduced cell count. After $72 \mathrm{~h}$ of cefazolin treatment, all cells treated with cefazolin showed a significantly lowered cell count, at $1000 \mu \mathrm{g} / \mathrm{mL}$ even lower than on day 0 . This shows that long treatment at high doses not only prevents cell proliferation but also results in cell death.

3.3. Cefazolin Irreversibly Inhibits Proliferation and Migration of $h M S C$. MSC cell lines treated with cefazolin for $24 \mathrm{~h}$ and $48 \mathrm{~h}$ were subsequently cultured for $72 \mathrm{~h}$ in media without the drug to give them time to recover. Proliferation and migration were determined as described above. The migration rate of cells treated for $24 \mathrm{~h}$ with $500 \mu \mathrm{g} / \mathrm{mL}(17.1 \%, p<0.05)$ and $1000 \mu \mathrm{g} / \mathrm{mL}$ cefazolin $(13.2 \%, p<0.01)$ was still significantly reduced compared to the control cells (23.7\%, Figure 3(a)). Cefazolin treatment for $48 \mathrm{~h}$ had even stronger effects that were also not compensated for during the recovery time. Compared to the migratory capacity of the control cells (23.5\%), that of MSCs treated with $100 \mu \mathrm{g} / \mathrm{mL}$ cefazolin (20.4\%, $p<0.05), 250 \mu \mathrm{g} / \mathrm{mL}(17.6 \%, p<0.01), 500 \mu \mathrm{g} / \mathrm{mL}$ (11.6\%, $p<0.001)$, and $1000 \mu \mathrm{g} / \mathrm{mL}(10.2 \%, p<0.001)$ remained significantly reduced. Similarly, compared to the control MSCs $\left(6.50 \times 10^{5}\right.$ cells $)$, even after $72 \mathrm{~h}$ of recovery time, the number of cells treated for $24 \mathrm{~h}$ with $500 \mu \mathrm{g} / \mathrm{mL}$ $\left(3.57 \times 10^{5}\right.$ cells, $\left.p<0.05\right)$ and $1000 \mu \mathrm{g} / \mathrm{mL}$ cefazolin $\left(2.91 \times 10^{5}\right.$ cells, $\left.p<0.01\right)$ was still significantly reduced (Figure 3(b)). Treatment for $48 \mathrm{~h}$ with cefazolin had stronger effects on the cells. Compared to untreated cells $\left(7.29 \times 10^{5}\right.$ cells), MSCs treated with $250 \mu \mathrm{g} / \mathrm{mL}\left(3.90 \times 10^{5}\right.$ cells, $p<$ $0.01), 500 \mu \mathrm{g} / \mathrm{mL}\left(1.83 \times 10^{5}\right.$ cells, $\left.p<0.01\right)$, and $1000 \mu \mathrm{g} / \mathrm{mL}$ cefazolin $\left(1.26 \times 10^{5}\right.$ cells, $\left.p<0.0001\right)$ had a significantly lower cell count.

\section{Discussion}

One of the most feared complications of arthroplasty is periprosthetic infection, which develops in $0.4-2 \%$ of patients [18]. Cefazolin, a $\beta$-lactam antibiotic and a firstgeneration cephalosporin, is effective against gram-positive bacteria (e.g., staphylococci, streptococci), some gramnegative bacteria (Escherichia coli and Klebsiella pneumoniae) and is on the World Health Organization's List of Essential Medicines (19th list, April 2015). It achieves highest peak bone concentrations of all first-generation cephalosporins $40 \mathrm{~min}$ after parenteral application with a serum half-life of $108 \mathrm{~min}$ and bone half-life of $42 \mathrm{~min}$ [3]. It is $90 \%$ bactericidal to $S$. aureus at concentrations greater than $100 \mu \mathrm{g} / \mathrm{mL}$ and eliminates bacteria within $48 \mathrm{~h}$ at concentrations of $250 \mu \mathrm{g} / \mathrm{mL}$ or within $24 \mathrm{~h}$ at $500 \mu \mathrm{g} / \mathrm{mL}$ [5]. Interestingly, there is a correlation between pharmacokinetics of antibiotics and body size measurements. Cefazolin differs in its tissue and body water distribution, which can therefore result in therapeutic failures or drug-related toxicities [7, 8]. In addition, there seems to be a significant correlation between younger age and higher cefazolin clearance [11]. Some authors recommend either systemic application of cefazolin, administration as an addition to bone cement, or local osseous application [19-21].

Bone healing is a dynamic process that is composed of stages of inflammation, repair, and remodelling. After the initial inflammatory process, MSCs are recruited to the trauma site, mediated by bone-morphogenetic-protein7 (BMP-7), stromal cell-derived factor-1 (SDF-1), and C-XC chemokine receptor type 4 (CXCR-4) [22, 23]. BMP-5 


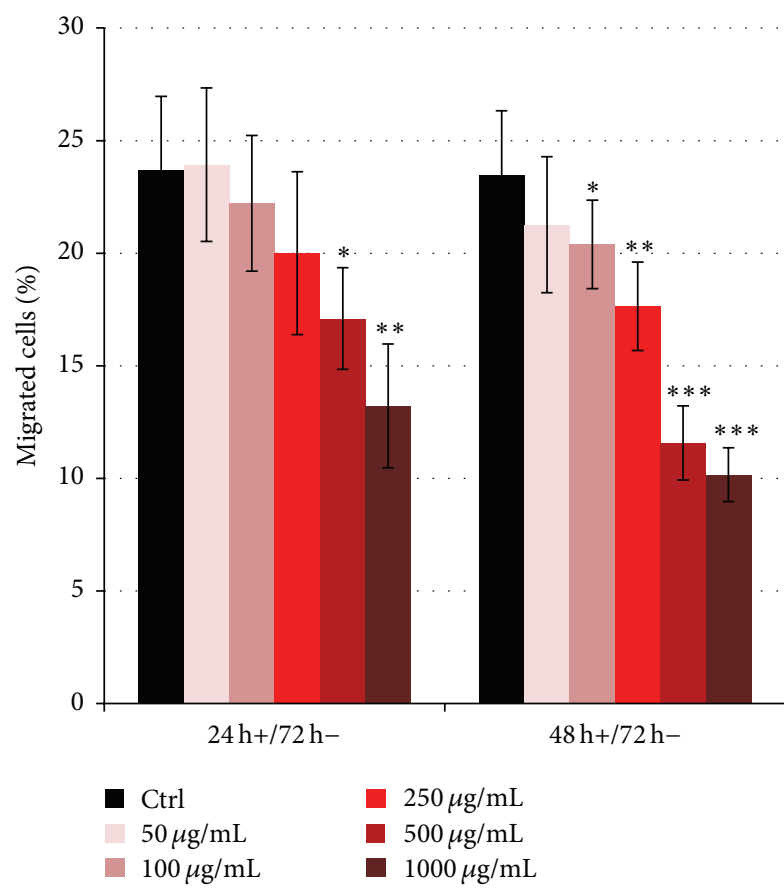

(a)

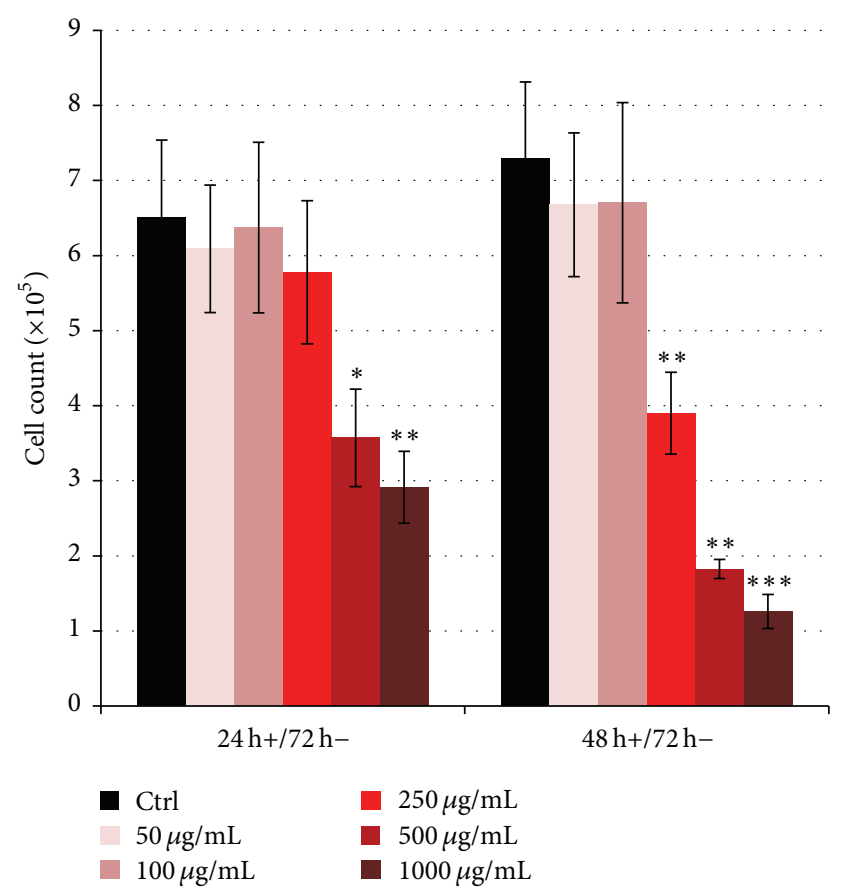

(b)

FIGURE 3: The effects of cefazolin on MSC migration and proliferation are irreversible. Bar charts showing (a) the proportion of mesenchymal stromal cells that migrated towards SDF-1 and (b) number of cells after $24 \mathrm{~h}$ or $48 \mathrm{~h}$ of cefazolin treatment with subsequent recovery for $72 \mathrm{~h}$ $(n=13)$. Asterisks show the level of significance $\left({ }^{*} p<0.05,{ }^{* *} p<0.01\right.$, and $\left.{ }^{* * *} p<0.001\right)$.

and BMP-6 have been suggested to induce cell proliferation $[24,25]$. After migration of MSCs to the trauma site and local proliferation, the differentiation cascade into osteoblasts is initiated by the Wnt family molecules. Finally, these mature osteoblasts carry out the remodelling process, starting 3-4 weeks after surgery [22].

In this study, we focused on the migratory and proliferative potential of human MSCs as the osteoblastic progenitor cells under cefazolin treatment in different concentrations. We found that cefazolin had an inhibitory effect on cell migration, as well as proliferation, in a time- and dosedependent manner. We showed for the first time that treatment for 48 or $72 \mathrm{~h}$ inhibited migration at doses of $\geq 100 \mu \mathrm{g} / \mathrm{mL}$ cefazolin and decreased proliferation even at doses as low as $50 \mu \mathrm{g} / \mathrm{mL}$, which is not even bactericidal [5]. Doses of $\geq 500 \mu \mathrm{g} / \mathrm{mL}$ cefazolin not only slowed down cell proliferation, but also led to cell death of the initial MSCs, which is in line with the effects this drug has been shown to have on osteoblasts [15]. Furthermore, we showed that the surviving cells were no longer able to migrate towards SDF-1 and, therefore, would not reach the trauma site. Our tests of whether these effects are reversible when the drug is removed showed that neither the migratory nor the proliferative potential of the MSCs recovered from cefazolin treatment. Therefore, our results show that cefazolin treatment for more than $24 \mathrm{~h}$, even at low doses, negatively affects MSC migration to and proliferation at the trauma site.
Furthermore, even during the short-term treatment of $24 \mathrm{~h}$, we could show that one dose of $\geq 250 \mu \mathrm{g} / \mathrm{mL}$ cefazolin inhibited the migration and proliferation of the MSCs. Our reversibility tests showed that neither the migratory nor the proliferative potential of the MSCs recovered from cefazolin treatment at doses of $>250 \mu \mathrm{g} / \mathrm{mL}$, which is the minimum recommended for $S$. aureus infections [5]. Therefore, even short-term administration of the minimum cefazolin dose of $\geq 250 \mu \mathrm{g} / \mathrm{mL}$ leads to irreversible effects on MSCs, thus slowing down their migration to the trauma site, as well as their on-site proliferation. Haasters et al. showed that reduction of migration and invasion of MSC resulted in a delay in callus formation and reducing endochondral ossification in osteoporotic patients [26].

Regarding antibiotic-impregnated cement or antibacterial coating of implants, our results add to the controversial discussion of these. While in a study with 22,889 total knee arthroplasties (TKA) there was no difference of the infection rate with and without antibiotic-loaded cement [27], others showed that cefuroxime-impregnated cement in addition to systemic cefazolin for 1 week in primary TKA decreases the infection rate to $0.19 \%$ in 2700 TKA [19]. Regarding cell toxicity, still others have shown very low metabolic activity, revealing a higher cytotoxic potential of antibiotic-coated prostheses, as well as a shift from osteogenic to adipogenic cell differentiation [28]. Therefore, regarding our results, we suppose that long-term administration of cefazolin can lead 
to delayed bone healing due to irreversible inhibition of migration and proliferation of MSCs, especially when there are local antibiotic concentration peaks due to antibioticloaded cement or implants. To verify whether these effects reflect clinical outcome further clinical studies are needed.

\section{Conclusion}

In this study, we demonstrate that cefazolin has an irreversible negative effect on migration and proliferation of primary human MSCs, which are the direct progenitors of osteoblasts, and therefore may play an inhibitory role in early stages of postoperative bone healing. Our data suggest that the balance between the targeted bactericidal effects and host cellular toxicity is critical for skeletal cell survival and function. Based on this in vitro study, we recommend that cefazolin should be administered only at the required dosage and only for shortterm use to avoid negative effects during bone healing.

\section{Competing Interests}

The authors declare that there are no competing interests.

\section{Authors' Contributions}

Hakan Pilge and Julia Fröbel contributed equally.

\section{References}

[1] B. Ponce, B. T. Raines, R. D. Reed, C. Vick, J. Richman, and M. Hawn, "Surgical site infection after arthroplasty: comparative effectiveness of prophylactic antibiotics: do surgical care improvement project guidelines need to be updated?" Journal of Bone and Joint Surgery-American Volume, vol. 96, no. 12, pp. 970-977, 2014.

[2] B. A. Ramo, D. W. Roberts, D. Tuason et al., "Surgical site infections after posterior spinal fusion for neuromuscular scoliosis: a thirty-year experience at a single institution," The Journal of Bone \& Joint Surgery-American Volume, vol. 96, no. 24, pp. 2038-2048, 2014.

[3] G. Bicanic, K. Crnogaca, K. Barbaric, and D. Delimar, "Cefazolin should be administered maximum 30 min before incision in total knee arthroplasty when tourniquet is used," Medical Hypotheses, vol. 82, no. 6, pp. 766-768, 2014.

[4] P. M. Courtneym, C. M. Melnic, Z. Zimmer, J. Anari, and G. C. Lee, "Addition of vancomycin to cefazolin prophylaxis is associated with acute kidney injury after primary joint arthroplasty," Clinical Orthopaedics and Related Research, vol. 473, no. 7, pp. 2197-2203, 2015.

[5] I. K. Yazdi, M. B. Murphy, C. Loo et al., "Cefazolin-loaded mesoporous silicon microparticles show sustained bactericidal effect against Staphylococcus aureus," Journal of Tissue Engineering, vol. 5, 2014.

[6] D. N. Williams, R. B. Gustilo, R. Beverly, and A. C. Kind, "Bone and serum concentrations of five cephalosporin drugs. Relevance to prophylaxis and treatment in orthopedic surgery," Clinical Orthopaedics and Related Research, no. 179, pp. 253-265, 1983.

[7] M. Sampson, M. Cohen-Wolkowiez, D. Benjamin Jr., E. Capparelli, and K. Watt, "Pharmacokinetics of antimicrobials in obese children," Generics and Biosimilars Initiative Journal, vol. 2, no. 2, pp. 76-81, 2013.

[8] R. Koshida, E. Nakashima, N. Taniguchi, A. Tsuji, L. Z. Benet, and F. Ichimura, "Prediction of the distribution volumes of cefazolin and tobramycin in obese children based on physiological pharmacokinetic concepts," Pharmaceutical Research, vol. 6, no. 6, pp. 486-491, 1989.

[9] G. M. Salzmann, F. D. Naal, F. von Knoch et al., "Effects of cefuroxime on human osteoblasts in vitro," Journal of Biomedical Materials Research A, vol. 82, no. 2, pp. 462-468, 2007.

[10] F. D. Naal, G. M. Salzmann, F. von Knoch et al., "The effects of clindamycin on human osteoblasts in vitro," Archives of Orthopaedic and Trauma Surgery, vol. 128, no. 3, pp. 317-323, 2008.

[11] S. van Kralingen, M. Taks, J. Diepstraten et al., "Pharmacokinetics and protein binding of cefazolin in morbidly obese patients," European Journal of Clinical Pharmacology, vol. 67, no. 10, pp. 985-992, 2011.

[12] J. P. Southwell-Keely, R. R. Russo, L. March, R. Cumming, I. Cameron, and A. J. Brnabic, "Antibiotic prophylaxis in hip fracture surgery: a metaanalysis," Clinical Orthopaedics and Related Research, no. 419, pp. 179-184, 2004.

[13] M. G. Dehne, J. Mühling, A. Sablotzki, H. Nopens, and G. Hempelmann, "Pharmacokinetics of antibiotic prophylaxis in major orthopedic surgery and blood-saving techniques," Orthopedics, vol. 24, no. 7, pp. 665-669, 2001.

[14] E. Paz, P. Sanz-Ruiz, J. Abenojar, J. Vaquero-Martín, F. Forriol, and J. C. Del Real, "Evaluation of elution and mechanical properties of high-dose antibiotic-loaded bone cement: comparative 'in vitro' study of the influence of vancomycin and cefazolin," Journal of Arthroplasty, vol. 30, no. 8, pp. 1423-1429, 2015.

[15] M. L. Edin, T. Miclau, G. E. Lester, R. W. Lindsey, and L. E. Dahners, "Effect of cefazolin and vancomycin on osteoblasts in vitro," Clinical Orthopaedics and Related Research, no. 333, pp. 245-251, 1996.

[16] N. M. C. Mathijssen, G. Hannink, P. Pilot, B. W. Schreurs, R. M. Bloem, and P. Buma, "Impregnation of bone chips with alendronate and cefazolin, combined with demineralized bone matrix: a bone chamber study in goats," BMC Musculoskeletal Disorders, vol. 13, article 44, 2012.

[17] Z. Zhang, X. Wang, F. Luo et al., "Effects of rifampicin on osteogenic differentiation and proliferation of human mesenchymal stem cells in the bone marrow," Genetics and Molecular Research, vol. 13, no. 3, pp. 6398-6410, 2014.

[18] L. Pulido, E. Ghanem, A. Joshi, J. J. Purtill, and J. Parvizi, "Periprosthetic joint infection: the incidence, timing, and predisposing factors," Clinical Orthopaedics and Related Research, vol. 466, no. 7, pp. 1710-1715, 2008.

[19] C.-C. Chiang and F.-Y. Chiu, "Cefuroxime-impregnated cement and systemic cefazolin for 1 week in primary total knee arthroplasty: an evaluation of 2700 knees," Journal of the Chinese Medical Association, vol. 75, no. 4, pp. 167-170, 2012.

[20] W. A. Jiranek, A. D. Hanssen, and A. S. Greenwald, "Antibioticloaded bone cement for infection prophylaxis in total joint replacement," The Journal of Bone and Joint Surgery. American, vol. 88, no. 11, pp. 2487-2500, 2006.

[21] S. W. Young, M. Zhang, J. T. Freeman, K. G. Vince, and B. Coleman, "Higher cefazolin concentrations with intraosseous regional prophylaxis in TKA," Clinical Orthopaedics and Related Research, vol. 471, no. 1, pp. 244-249, 2013.

[22] R. Marsell and T. A. Einhorn, "The biology of fracture healing," Injury, vol. 42, no. 6, pp. 551-555, 2011. 
[23] F. Granero-Moltó, J. A. Weis, M. I. Miga et al., "Regenerative effects of transplanted mesenchymal stem cells in fracture healing," Stem Cells, vol. 27, no. 8, pp. 1887-1898, 2009.

[24] K. Tsuji, A. Bandyopadhyay, B. D. Harfe et al., "BMP2 activity, although dispensable for bone formation, is required for the initiation of fracture healing," Nature Genetics, vol. 38, no. 12, pp. 1424-1429, 2006.

[25] R. Marsell and T. A. Einhorn, "The role of endogenous bone morphogenetic proteins in normal skeletal repair," Injury, vol. 40, supplement 3, pp. S4-S7, 2009.

[26] F. Haasters, D. Docheva, C. Gassner et al., "Mesenchymal stem cells from osteoporotic patients reveal reduced migration and invasion upon stimulation with BMP-2 or BMP-7," Biochemical and Biophysical Research Communications, vol. 452, no. 1, pp. 118-123, 2014.

[27] R. S. Namba, Y. Chen, E. W. Paxton, T. Slipchenko, and D. C. Fithian, "Outcomes of routine use of antibiotic-loaded cement in primary total knee arthroplasty," Journal of Arthroplasty, vol. 24, no. 6, pp. 44-47, 2009.

[28] F. D. Matl, A. Obermeier, S. Repmann, W. Friess, A. Stemberger, and K.-D. Kuehn, "New anti-infective coatings of medical implants," Antimicrobial Agents and Chemotherapy, vol. 52, no. 6, pp. 1957-1963, 2008. 


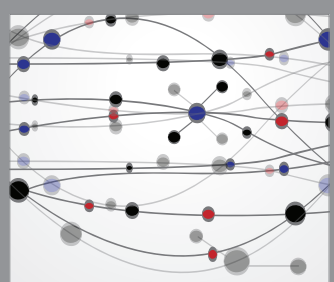

The Scientific World Journal
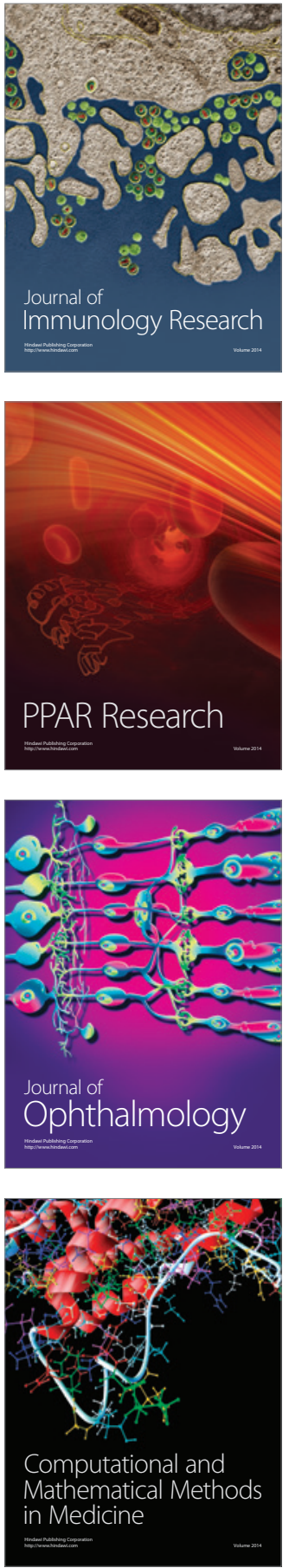

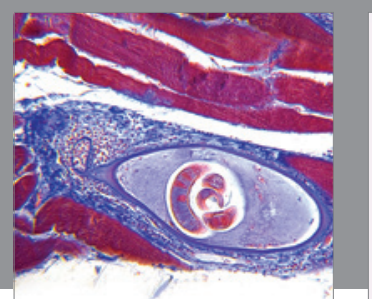

Gastroenterology Research and Practice

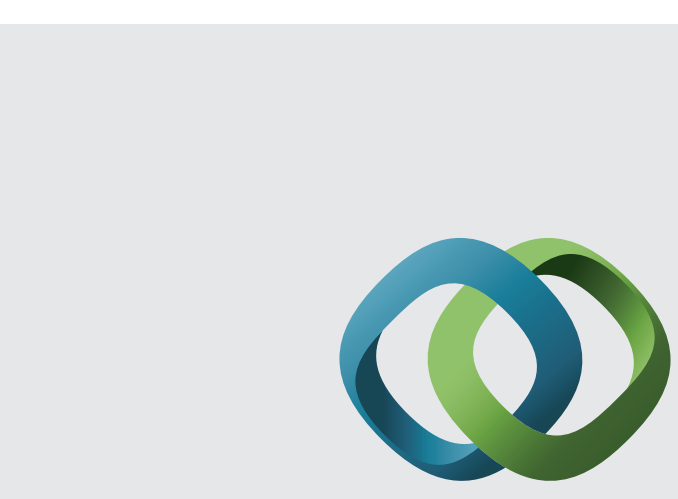

\section{Hindawi}

Submit your manuscripts at

http://www.hindawi.com
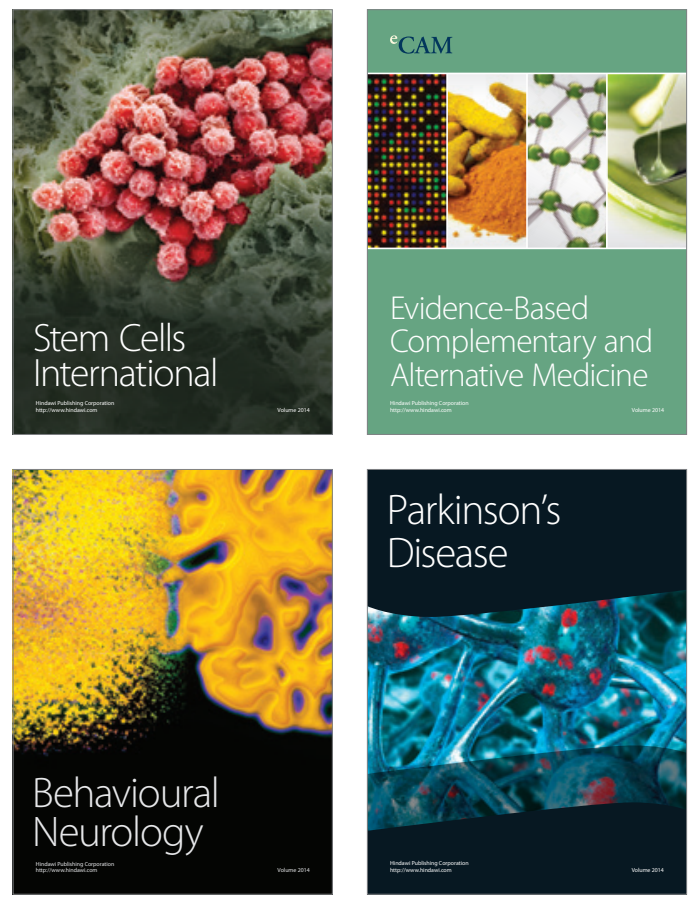
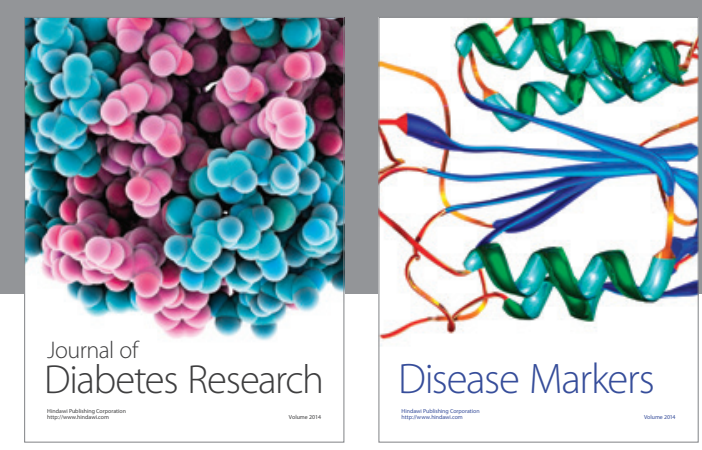

Disease Markers
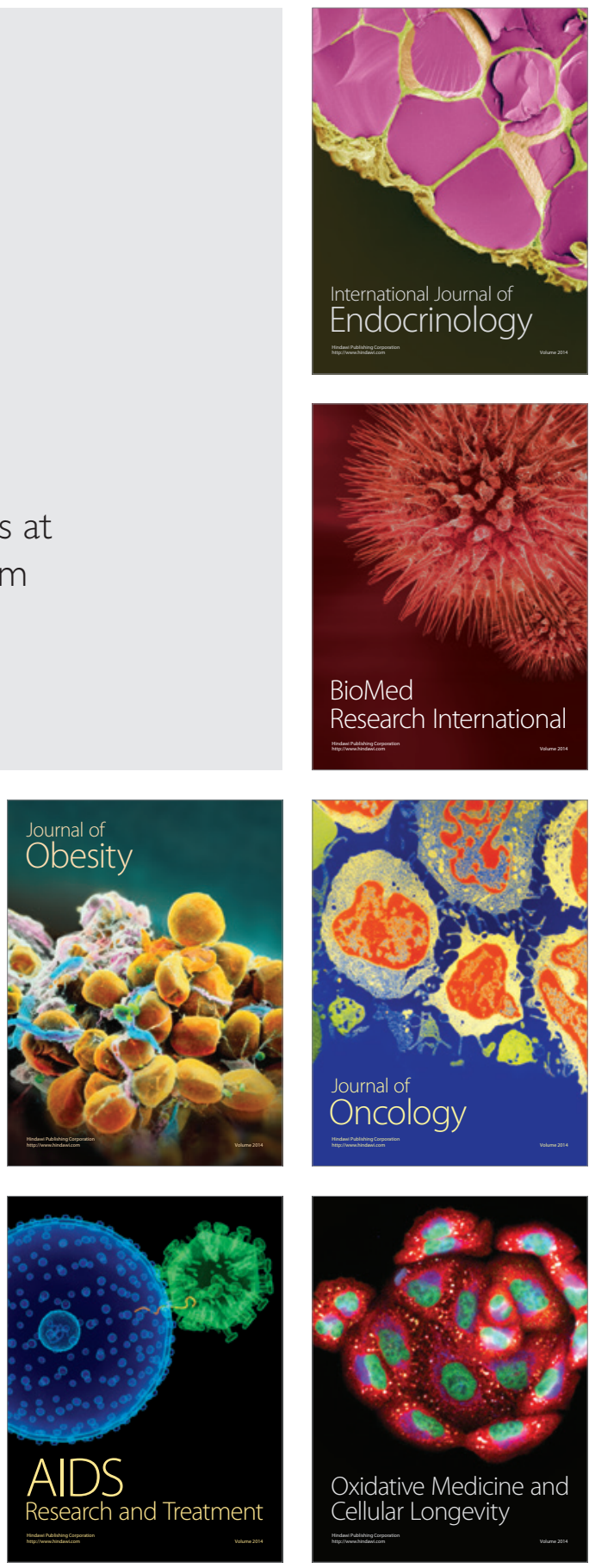